\title{
Międzynarodowa Konferencja Naukowa nt.: „Transformacja systemów wymiaru sprawiedliwości w państwach Europy Środkowej i Wschodniej w latach 1990-2010", Legnica, 10-11 kwietnia 2010 r.
}

W dniach 10-11 kwietnia 2010 r. w Legnicy odbyła się Międzynarodowa Konferencja Naukowa „Transformacja systemów wymiaru sprawiedliwości w państwach Europy Środkowej i Wschodniej w latach 1990-2010”. Organizatorem Konferencji było Międzynarodowe Centrum Prawa i Zarządzania Wyższej Szkoły Menedżerskiej w Legnicy, które zrealizowało przedsięwzięcie we współpracy z Biurem Informacji Rady Europy w Warszawie, Fundacją Praw Podstawowych w Warszawie oraz Fundacją Promocji Prawa Europejskiego w Warszawie. Honorowy patronat nad Konferencją sprawował Pierwszy Prezes Sądu Najwyższego. W skład zaś powołanego Komitetu Honorowego Konferencji weszli najwybitniejsi praktycy władzy sądowniczej w Polsce. Gwarancją najwyższego poziomu Konferencji byli nie tylko jej organizatorzy, zaproszeni prelegenci, ale także Komitet Naukowy Konferencji, złożony z trzydziestu ośmiu luminarzy nauki o władzy sądowniczej tak z Polski, jak i - co wychodziło naprzeciw umiędzynarodowieniu Konferencji - spoza jej granic.

Organizatorom Konferencji udało się zaprosić - co samo w sobie jest wydarzeniem świadczącym o jej wadze nie tylko dla rodzimej refleksji nad dynamiką polskiego wymiaru sprawiedliwości ostatnich dwudziestu lat, dylematów z nią związanych, ale zarazem dla w ogóle europejskiej i centralno-azjatyckiej nauki o władzy sądowniczej - najwybitniejszych prelegentów z dziesięciu państw, przy czym z samej Federacji Rosyjskiej udało się organizatorom zaprosić jedenastu akademików, $\mathrm{z}$ takich ośrodków naukowych jak moskiewski (Moskowskaja Gosudarstwiennaja Juridiczeskaja Akademija im. O. J. Kutafina, GOU WPO Rossijskaja Akadiemija Prawosudija), orłowski (Orłowskij Gosudarstwiennyj Tiechniczeskij Uniwiersitiet), tambowski (Tambowskij Gosudarstwiennyj Uniwiersitiet im. G. W. Dierżawina), woroneżski (Woroneżskij Gosudarstwiennyj Uniwiersitiet).

Otwarcia Konferencji dokonał profesor Jerzy Jaskiernia - dyrektor Międzynarodowego Centrum Prawa i Zarządzania. Przybyłych z kraju i zagranicy gości przywitali również mgr inż. Wacław Demecki - założyciel Wyższej Szkoły Mene- 
dżerskiej w Legnicy oraz jej rektor - profesor Jerzy Mączyński. W trakcie odczytywania przesłanego uczestnikom Konferencji listu wicemarszałka Sejmu RP Jerzego Szmajdzińskiego dotarła do uczestników Konferencji informacja o katastrofie lotniczej pod Smoleńskiem, w której zginęli przedstawiciele najwyższych władz Rzeczypospolitej Polskiej i inne osoby zasłużone dla Państwa Polskiego. Informacja o katastrofie spowodowała przerwanie obrad. Po ich wznowieniu zgromadzeni minutą ciszy uczcili pamięć tragicznie zmarłych Polaków.

Pierwszego dnia obrad odbyły się dwie sesje plenarne. Pierwsza z nich była poświęcona zagadnieniom modelowym, wyznaczającym standardy w ustrojowym uporządkowaniu władzy sądowniczej, tj. pozycji władzy sądowniczej w systemie demokratycznym; druga z kolei miała bardziej charakter funkcjonalny i pokazywała wyzwania dla władzy sądowniczej w dobie transformacji. Z jednej strony diagnozowała sumę dylematów rozwiązywanych w państwach Europy Środkowej i Wschodniej w ciągu ostatnich dwudziestu lat w zakresie kształtowania władzy sądowniczej, ale zarazem czyniła projekcję procesów i zjawisk, jakie odpowiednio mogą czy powinny nastąpić w najbliższych latach.

Sesje plenarne zostały uzupełnione ośmioma panelami tematycznymi, poświęconymi refleksji nad poszczególnymi aspektami władzy sądowniczej. Były one prowadzone w dwóch turach, po cztery w każdej. W pierwszej turze panele tematyczne dotykały następujących problematyk: konstytucyjnych zasad wymiaru sprawiedliwości, ustrojowego usytuowania władzy sądowniczej, problemów wymiaru sprawiedliwości w dobie transformacji ustrojowej oraz teoretycznych problemów wymiaru sprawiedliwości. Panele tematyczne natomiast zrealizowane w drugiej turze ogniskowały rozważania w ramach następujących zagadnień: wpływ procesu integracji europejskiej na transformację wymiaru sprawiedliwości, realizacja standardów europejskich w wymiarze sprawiedliwości, transformacja sądownictwa konstytucyjnego i instytucji odpowiedzialności konstytucyjnej oraz transformacja systemu prokuratury. Panele tematyczne stały się główną płaszczyzną konfrontowania refleksji nad poszczególnymi problematykami wymiaru sprawiedliwości, poszukiwania w tym zakresie prawidłowości ustrojowych i odpowiedzi na pytania, czy dotychczas wypracowane instytucje wymiaru sprawiedliwości wyznaczają optimum możliwości państw współczesnych, czy też przeciwnie, jesteśmy w stanie zdiagnozować w nich istotne rezerwuary niewykorzystanych możliwości, czekających na swą reorganizację i wprowadzenie do praktyki władzy sądowniczej.

Drugiego dnia obrad miały miejsce dwie, kompatybilne względem siebie, sesje plenarne. Motywem przewodnim pierwszej z nich było funkcjonowanie władzy 
sądowniczej w demokratycznym społeczeństwie, drugiej natomiast- wpływ procesu integracji europejskiej na funkcjonowanie wymiaru sprawiedliwości.

Zwrócić należy uwagę na kompleksowość problematyk poddanych naukowej eksploracji w ramach Konferencji. Obok rozważań systemowych, kierunkowych, pokazujących ustrojowe uwarunkowania i konsekwencje transformacji systemów wymiaru sprawiedliwości w państwach Europy Środkowej i Wschodniej w latach 1990-2010, udało się również poddać analizie poszczególne składowe systemów wymiaru sprawiedliwości tak na poziomie regulacji prawa międzynarodowego (w szczególności w systemie Rady Europy), prawa wspólnotowego, zasad konstytucyjnych, jak i ustroju organów władzy sądowniczej, procedury sądowego postępowania.

Międzynarodową Konferencję Naukową „Transformacja systemów wymiaru sprawiedliwości w państwach Europy Środkowej i Wschodniej w latach 19902010" zakończyły wystąpienia podsumowujące organizatorów wydarzenia: profesora Jerzego Jaskiernii - dyrektora Międzynarodowego Centrum Prawa i Zarządzania, mgra inż. Wacława Demeckiego - założyciela Wyższej Szkoły Menedżerskiej w Legnicy oraz jej rektora - profesora Jerzego Mączyńskiego.

Jacek Zaleśny Uniwersytet Warszawski 